\title{
CAN WE MAKE THE OCEANS \\ GREENER? THE SUCCESSES AND \\ FAILURES OF UNCLOS AS AN \\ ENVIRONMENTAL TREATY
}

Joanna Mossop*

At the conclusion of the United Nations Convention on the Law of the Sea (UNCLOS) in 1982, there was considerable optimism that the Convention would usher in a new age of marine environmental protection. This article argues that, while UNCLOS did contain important innovations for marine environmental protections, key structural problems prevented the Convention from fulfilling more optimistic predictions of success. Concepts such as freedom of the high seas and exclusive flag state jurisdiction as well as the lack of an effective institution with competence over the law of the sea generally have impeded progress. Instead, states have relied on incremental development to seek improvements in the law. The article evaluates whether two recent developments will progress the goal of marine environmental protection. First, a number of recent international judicial decisions interpreting treaty and customary principles of international law have clarified and extended state environmental obligations. Second, negotiations for a new treaty on the protection and sustainable use of biodiversity in areas beyond national jurisdiction offer hope that gaps in UNCLOS might be filled.

\section{INTRODUCTION}

The United Nations Convention on the Law of the Sea (UNCLOS) ${ }^{1}$ has been described as an environmental treaty that established a dynamic international legal framework for the protection of the marine environment. ${ }^{2}$ In 1992, Philip Allott argued that UNCLOS was a "slow-motion

* Associate Professor, Law Faculty, Victoria University of Wellington.

1 United Nations Convention on the Law of the Sea 1833 UNTS 3 (opened for signature 10 December 1982, entered into force 16 November 1994) [UNCLOS].

2 James Harrison Saving the Oceans through Law: The International Legal Framework for the Protection of the Marine Environment (Oxford University Press, Oxford, 2017) at 304. 
metamorphosis". ${ }^{3}$ He claimed that UNCLOS was "a half-formed new structural uniqueness, full of painful ambiguities and exciting possibilities". 4 Allott viewed UNCLOS as a combination of oldfashioned international law based on conceptions of property and a move towards a governance approach to achieving social objectives, including the protection of the marine environment. ${ }^{5}$ This article asks whether the metamorphosis that Allott so optimistically forecast has been fulfilled. In other words, has the law of the sea emerged as a fully-developed system to achieve the vital objective of protecting the environment?

There is no doubt that UNCLOS was a momentous step towards environmental protection of the oceans. Subsequent developments include the negotiation of a myriad of new, sectorally-focused treaties, many of which have the environment as a key consideration. Despite these advances, however, the state of the ocean environment has worsened in a number of important respects. ${ }^{6}$ The number of fish stocks that are overfished has increased over time rather than decreased, despite the existence of a number of regional fisheries management organisations which are responsible for achieving sustainable catches. It is estimated that 90 per cent of top predators in the oceans have been depleted from pre-industrial levels. ${ }^{7}$ In many parts of the world, destructive fishing practices heavily impact on marine ecosystems. Plastic pollution of the ocean has become recognised as one of the biggest threats to healthy oceans. Another significant threat is the impact of climate change, although that has yet to be adequately addressed. ${ }^{8}$

This article seeks to evaluate why, in some important respects, the law of the sea has not been able to respond adequately to new and old environmental problems. In some ways, UNCLOS facilitated steady improvements in environmental protection. However, in other ways the structure and content of UNCLOS has slowed, and in some cases prevented, the dynamic evolution of the law of the sea for environmental protection. In other words, the promise of Allott's metamorphosis has not been achieved. The article takes fisheries and marine biodiversity as two examples of fields in which progress has been difficult.

3 Philip Allott "Mare Nostrum: A New International Law of the Sea" (1992) 86 AJIL 764 at 765.

4 At $765-766$.

5 At 786

6 See Duncan Currie "The Oceans: the Law of the Sea Convention as a form of global governance" (2017) 13(1) PQ 32.

7 Ransom A Myers and Boris Worm "Rapid worldwide depletion of predatory fish communities" (2003) 423 Nature 280 at 282.

8 Tim Stephens "Warming Waters and Souring Seas: Climate Change and Ocean Acidification" in Donald R Rothwell and others (eds) The Oxford Handbook of the Law of the Sea (Oxford University Press, Oxford, 2015) 777. 
Despite the problems caused by the structure of UNCLOS, incremental progress to improve the legal framework has been made. This article highlights two recent developments which may be important steps towards filling some of the governance gaps left by the Convention. First, there appears to be an increasing willingness by dispute settlement bodies to use customary international law and general principles in UNCLOS to clarify state obligations in respect of the environment. Second, the international community is currently undertaking negotiations for a new implementing treaty addressing the sustainable use of marine biodiversity in areas beyond national jurisdiction. However, the article demonstrates that significant obstacles stand in the way of these developments being as effective as they could be.

\section{LAW OF THE SEA PRIOR TO 1982}

The development of the law of the sea for many centuries was primarily about power and economics: who controlled maritime areas and resources in areas close to the coasts, balanced with the need for merchant ships and navies to conduct their businesses on the important maritime highways of the world. A key motivation for the push for control over territorial seas was the desire of coastal states to ensure that the fishing resources of the coastal waters were reserved for the exclusive use of the coastal state. ${ }^{9}$ This was primarily a concern to protect economic interests rather than about protection of the environment. ${ }^{10}$

It was clear that in isolated areas marine resources could be exhausted by overharvesting. The Pacific Fur Seals Arbitration in 1893 was a good example of a situation in which international dispute settlement was used to try to resolve a practical problem created by excessive harvesting of a finite resource - seals. ${ }^{11}$ Although on the one hand it can be classified as an environmental dispute - the impact of harvesting on the seal population - in most respects the dispute was about the need to have distributive rules to prevent the overexploitation of a resource. Other examples of this phenomenon include the development of the international instruments designed to regulate whaling. ${ }^{12}$

Regional fisheries management organisations (RFMOs) began to emerge as states came to recognise that fish stocks were also vulnerable to overfishing. Some of the earlier RFMOs that were created include the Inter-American Tropical Tuna Commission (1949), the General Fisheries Council

9 RR Churchill and AV Lowe The law of the sea (3rd ed, Manchester University Press, Manchester, 1999) at 72 .

10 Allott, above n 3, at 767.

11 Award between the United States and the United Kingdom relating to the rights of jurisdiction of United States in the Bering's sea and the preservation of fur seals (1893) 28 RIAA 263. See Donald R Rothwell and Tim Stephens The International Law of the Sea (2nd ed, Hart Publishing, Oxford, 2016) at 316.

12 Convention for the Regulation of Whaling 155 LNTS 349 (opened for signature 24 September 1931, entered into force 16 January 1935); and International Convention for the Regulation of Whaling 161 UNTS 72 (opened for signature 2 December 1946, entered into force 10 November 1948). 
for the Mediterranean (1952) and the International Commission for the Conservation of Atlantic Tunas (1966).

Concern also began to grow about the impact of pollution on the marine environment. The International Maritime Organization, which was established in 1948 to focus on safety at sea, began to also address issues arising from pollution. In 1967, the Torrey Canyon incident highlighted the dangers for the marine environment when an oil tanker ran aground off the coast of England, spilling 117,000 tonnes of oil. ${ }^{13}$ Although some international conventions already existed for protecting the marine environment at that stage, ${ }^{14}$ the following decade saw a flurry of conventions negotiated under the auspices of the International Maritime Organization. ${ }^{15}$

\section{THE UNITED NATIONS CONVENTION ON THE LAW OF THE SEA AS AN ENVIRONMENTAL TREATY}

In 1972 the United Nations Conference on the Human Environment in Stockholm recommended that governments implement existing instruments for controlling marine pollution and take other steps to monitor and prevent such pollution. ${ }^{16}$ However, at the commencement of the Third United Nations Conference on the Law of the Sea in 1973, there was no "generally accepted framework or structure of legal principles capable of dealing with the full range of marine pollution problems". ${ }^{17}$ It is therefore notable that Part XII of UNCLOS creates an extensive framework for marine protection. Allott suggested that Part XII represented "the new wine of communitarianism spilling over from the old bottle of legal formalism". 18

Part XII contains a number of general principles requiring states to take steps to prevent, reduce and control harm to the marine environment. The focus is very much on pollution, although not all of

13 ED Brown "The Lessons of the Torrey Canyon: International Law Aspects" (1968) 21 CLP 113.

14 International Convention for the Prevention of Pollution of the Sea by Oil 327 UNTS 3 (opened for signature 12 May 1954, entered into force 26 July 1958), modified by amendments in 1962 and 1969.

15 International Convention relating to intervention on the high seas in cases of oil pollution casualties 970 UNTS 211 (opened for signature 29 November 1969, entered into force 6 May 1975); International Convention on Civil Liability for Oil Pollution Damage 973 UNTS 3 (opened for signature 29 November 1969, entered into force 19 June 1975); Convention on the Prevention of Marine Pollution by Dumping of Wastes and Other Matter 1046 UNTS 138 (opened for signature 29 December 1972, entered into force 30 August 1975); and Protocol of 1978 relating to the International Convention for the prevention of pollution from ships, 19731340 UNTS 61 (opened for signature 17 February 1978, entered into force 2 October 1983).

16 Report of the United Nations Conference on the Human Environment UN Doc A/CONF.48/14/Rev.1 (1972) at $22-24$.

17 Alan E Boyle "Marine Pollution under the Law of the Sea Convention" (1985) 79 AJIL347 at 348.

18 Allott, above n 3, at 785 . 
the general principles are limited to pollution. ${ }^{19}$ Part XII also establishes a framework outlining which states have jurisdiction over vessels that may pollute the marine environment and creates safeguards for vessels accused of polluting. UNCLOS does not create specific standards for pollution, rather it elaborates the general principles and obligations and recognises that the specific standards will be implemented through other international instruments. ${ }^{20}$

Beyond Part XII, however, the influence of environmental principles is far less pervasive. In relation to fisheries in the exclusive economic zone (EEZ), UNCLOS requires coastal states to promote optimum utilisation in their EEZs, ${ }^{21}$ while ensuring that the living resources there are not endangered by overexploitation. ${ }^{22}$ States are instructed to restore or maintain stocks at the maximum sustainable yield. ${ }^{23}$ These requirements were driven in part by an economic rationality that fish stocks should be exploited, but not so extensively that they be overfished (and thus potentially impact on other stocks beyond the EEZ). However, UNCLOS does have some reference to environmental principles beyond the management of fish stocks for economic purposes. Coastal states are instructed to take into account the effects of management measures on associated species so as not to endanger such species, but this is a long way from requiring an ecosystem approach to fisheries management. Part VI imposes no specific environmental obligations on coastal states in respect of sedentary species on the continental shelf.

On the high seas, the freedom to fish is subject to the duty to cooperate with other states to take measures to conserve living resources, including establishing RFMOs. ${ }^{24}$ States must aim to maintain or restore fish populations at levels which can produce the maximum sustainable yield, and there is another instruction to take into account associated or dependent species when agreeing on measures on the high seas.

The need to protect the marine environment is found in other parts of UNCLOS. The regime for the seabed beyond national jurisdiction instructs the International Seabed Authority to adopt rules for the prevention, reduction and control of pollution from activities on the seabed and to protect and conserve the flora and fauna of the marine environment. ${ }^{25}$ Coastal states may take steps in areas under

19 See for example arts 192 and 206.

20 Article 237.

21 Article 62(1)

22 Article 61(2).

23 Article 61(3). For a critique of this approach see Ellen Hey "The Persistence of a Concept: Maximum Sustainable Yield" (2012) 27 IJMCL 763.

24 Articles 117-118.

25 Article 145. 
their jurisdiction, including the territorial $\mathrm{sea}^{26}$ and EEZ, ${ }^{27}$ to protect the marine environment. Coastal states may also refuse permission for marine scientific research in the EEZ and on the continental shelf where the project might introduce harmful substances into the marine environment. ${ }^{28}$

UNCLOS provided a significant leap forward in environmental protection, particularly in the area of marine pollution, as the first truly global response to the problem. ${ }^{29}$ However, its provisions in relation to regulating the environmental effect of other activities, especially fisheries, were limited in scope. Following the conclusion of the Convention, it became clear that the expansion of coastal state jurisdiction over 90 per cent of the world's fish stocks had not eliminated problems. In particular, straddling and highly migratory stocks appeared to pose a significant cooperation challenge that the international community was not able to solve based solely on UNCLOS.

\section{THE SUCCESSES OF UNCLOS AS AN ENVIRONMENTAL TREATY}

Bernard Oxman has argued that successful environmental regulation requires universality, precision, adaptability and legal obligation. ${ }^{30}$ Although the requirement for legality as a criterion of success has been contested, ${ }^{31}$ in some respects UNCLOS has met these criteria.

There can be no doubt that Part XII of UNCLOS has clarified the roles and obligations of flag and coastal states in relation to pollution measures, especially discharges from ships. A particularly important feature of the Convention is that it allows states to establish laws in their maritime zones "giving effect to generally accepted international rules and standards established through the competent international organization or general diplomatic conference". ${ }^{32}$ This reference to "generally accepted" rules and standards is repeated, in varying forms, in Part XII and in other parts of the Convention. For example, UNCLOS requires that states put in place rules around dumping that are "no less effective in preventing, reducing and controlling such pollution than the global rules and

26 Article 21(1)

27 Article 211(5).

28 Article 246(5).

29 Moira L McConnell and Edgar Gold "The Modern Law of the Sea: Framework for the Protection and Preservation of the Marine Environment?" (1991) 23 Case W Res J Intl L 83 at 85.

30 Bernard H Oxman "The Duty to Respect Generally Accepted International Standards" (1991) 24 NYU J Intl Law \& Pol 109 at 111-113.

31 See for example Edith Brown Weiss "Understanding Compliance with International Environmental Agreements: The Baker's Dozen Myths" (1999) 32 U Rich L Rev 1555 at 1566; Kal Raustiala "Compliance \& Effectiveness in International Regulatory Cooperation" (2000) 32 Case W Res J Intl L 387 at 423; and Kal Raustiala "Form and Substance in International Agreements" (2005) 99 AJIL 581 at 612.

32 Article 211(5). 
standards". 33 Article 94(5) requires flag states to conform to generally accepted international regulations, procedures and practices when establishing regulation of their vessels. The effect of such "rules of reference" in many cases is to allow states to enforce generally accepted international rules and standards against all vessels in their maritime zones, including those flagged to states that may not have accepted the particular treaty or rule. ${ }^{34}$

The enforcement powers of coastal states were also strengthened under Part XII. Rather than relying solely on the flag state to enforce violations of rules that led to pollution outside the territorial sea, UNCLOS clarified and even extended the enforcement rights of non-flag states. In particular, Article 218 gave powers to port states to take steps to "institute proceedings" against vessels that have polluted in another state's maritime zones or on the high seas in contravention of "applicable international rules and standards established through the competent international organization". Although the flag state retains the ability to take over the investigation and enforcement, the extension of rights to port states has dramatically increased the possibility that vessels violating international standards and causing pollution can be held accountable. ${ }^{35}$

Boyle has argued that UNCLOS is comprehensive, in that it covers all forms of marine pollution, and "reflects a fundamental shift from power to duty as the central controlling principle of the legal regime for the protection of the marine environment". ${ }^{36}$ It has created a base on which to build further rules.

Regardless of this praise, it cannot be said that Part XII is an unmitigated success. Many of the provisions in Part XII are phrased in a relatively weak way, including the articles on atmospheric and land-based pollution. ${ }^{37}$ There has also been some doubt about where and when broad provisions such as Article 192's general obligation to protect and preserve the marine environment apply to other activities such as fishing in a way to impose specific obligations. ${ }^{38}$

33 Article 210(6). See also arts 21, 94(5), 60, 208(3) and 211.

34 On rules of reference, see generally James Harrison Making the Law of the Sea: A Study in the Development of International Law (Cambridge University Press, Cambridge, 2011) at 165-179; Oxman, above n 30, at 122-139; and W van Reenen "Rules of Reference in the new Convention on the Law of the Sea, in particular in connection with the pollution of the sea by oil from tankers" (1981) 12 NYIL 3.

35 For a view that not enough power was given to coastal states see Daniel Bodansky "Protecting the Marine Environment from Vessel-Source Pollution: UNCLOS III and Beyond" (1991) 18 Ecology LQ 719 at 768.

36 Boyle, above n 17, at 370 .

37 At 354

38 Valentin Schatz "Fishing for Interpretation: The ITLOS Advisory Opinion on Flag State Responsibility for Illegal Fishing in the EEZ" (2016) 47 Ocean Dev \& Intl L 327 at 333-334. 


\section{THE LIMITATIONS OF UNCLOS AS AN ENVIRONMENTAL TREATY}

There has been no shortage of academic commentators over the years pointing out the difficulties and problems in relying on UNCLOS to improve environmental protection. With regards to Oxman's criteria, it is possible to see that UNCLOS has particular problems with achieving universality, precision and adaptability in some contexts.

\section{A Structural Limitations with UNCLOS}

There are a number of weaknesses in the structure of UNCLOS, and the law of the sea generally, that make it difficult to achieve progress on environmental protection.

One concern is that the rhetoric of "freedom" that underpins activities on the high seas is an impediment to convincing states that activities should be curtailed in order to protect the marine environment. Rayfuse refers to the freedom of the high seas as an anachronistic "theoretical foundation of the law of the sea". ${ }^{39}$ As she rightly points out, this rhetoric is outdated for two reasons. First, the freedom of fishing was based on the idea that the living marine resources were inexhaustible; however, we now understand that this is not the case. ${ }^{40}$ Second, a number of limitations on the freedom of the high seas have developed over time. ${ }^{41}$ These include limitations imposed by UNCLOS itself as well as in a range of other treaties. Despite this, states are often reluctant to accept further voluntary limitations due to the common property regime that has been established. ${ }^{42}$ Rayfuse argues that: ${ }^{43}$

... this reification of the freedom, or at any rate of the rhetoric of freedom, hinders the ability of the law of the sea to develop in a way that addresses the multiple challenges posed by contemporary and emerging ocean uses.

39 Rosemary Rayfuse "Some Reflections on What's Wrong with the Law of the Sea" in Cedric Ryngaert, Erik J Molenaar and Sarah MH Nouwen (eds) What's Wrong with International Law? - Liber Amicorum AHA Soons (Brill, Leiden, 2015) 16 at 17.

40 At 17.

41 At 18.

42 Rosemary Rayfuse and Robin Warner "Securing a Sustainable Future for the Oceans Beyond National Jurisdiction: The Legal Basis for an Integrated Cross-Sectoral Regime for High Seas Governance for the 21st Century" (2008) 23 IJMCL 399 at 407.

43 Rayfuse, above n 39, at 19. 
A second structural difficulty, connected to the first, is the strong dependence on exclusive flag state jurisdiction and the existence of flags of convenience. ${ }^{44}$ This leads to problems achieving universal coverage of treaty norms. UNCLOS establishes that vessels on the high seas are entitled to fly the flag of a state, which has exclusive jurisdiction over that vessel while it is in the high seas. ${ }^{45}$ Exclusive flag state jurisdiction makes sense if one assumes that all states will take responsibility for enforcing international standards on their vessels and punishing violations of the law. Unfortunately, many states are not willing - or are unable - to exercise effective control over vessels flying their flags. This means that states may have little ability to prevent vessels flagged to other states that are blatantly violating international legal rules on the high seas.

There are very limited cases in which one state can exercise jurisdiction over another state's vessels on the high seas. ${ }^{46}$ These include piracy, which is the only case in which universal enforcement jurisdiction exists. Many fewer rights, primarily involving a right to visit, are available when the vessel is involved in slave trading or unauthorised broadcasting. ${ }^{47}$ There have been attempts to broaden the situations in which non-flag states can board a vessel on the high seas through treaties such as the ship boarding regimes embodied in the United Nations Fish Stocks Agreement (UNFSA) ${ }^{48}$ While this has had some effect in RFMO regimes, it is still dependent on a state agreeing to be party to either the UNFSA or a relevant RFMO. A truly recalcitrant state is able to avoid all obligations and avoid sanctions for its vessels operating contrary to treaty-based restrictions designed to protect the environment.

A third structural problem can be identified if UNCLOS is compared to multilateral environmental agreements (MEAs). The majority of MEAs create institutions to make decisions about the operation of the regime, develop new rules where necessary and improve enforcement. These include a

44 H Edwin Anderson "The Nationality of Ships and Flags of Convenience: Economics, Politics, and Alternatives" (1996) 21 Tul Mar LJ 139; and Jessica K Ferrell "Controlling Flags of Convenience: One Measure to Stop Overfishing of Collapsing Fish Stocks" (2005) 35 Envtl L 323.

45 UNCLOS, art 92.

46 Article 110

47 In the case of unauthorised broadcasting, there are some states other than the flag state that can prosecute offenders, including the state which is receiving the broadcasting and the state of which the offender is a national: art 109.

48 Agreement for the Implementation of the Provisions of the United Nations Convention on the Law of the Sea of 10 December 1982 relating to the Conservation and Management of Straddling Fish Stocks and Highly Migratory Fish Stocks 2167 UNTS 3 (opened for signature 4 December 1995, entered into force 11 December 2001). See also Protocol of 2005 to the Protocol for the Suppression of Unlawful Acts against the Safety of Fixed Platforms Located on the Continental Shelf (opened for signature 14 October 2005, entered into force 28 July 2010), which allows states to voluntarily accept processes allowing other states to board their vessels. No states have so far declared their willingness to waive their exclusive flag state jurisdiction even in cases of serious maritime crimes. 
Conference of the Parties, a secretariat, technical and scientific committees and often compliance committees. ${ }^{49}$ This approach to establishing institutions leads to more adaptable regimes because there is a process for updating and amending current measures. There are sectoral bodies in the law of the sea that are certainly capable of performing these functions, such as the International Seabed Authority, the International Maritime Organization and RFMOs. However, these institutions are sectoral rather than comprehensive in nature, focusing on a specific range of issues. In the case of RFMOs they may have limited competence to deal with all fish species or broader environmental issues. Regional seas programmes (RSPs) are a possible option for achieving more comprehensive governance of a region, but there are relatively few RSPs that are effectively exercising this role. ${ }^{50}$ There is a regular meeting of states party to UNCLOS, but it has a very circumscribed role limited to administrative and financial matters. ${ }^{51}$ The General Assembly has contributed by passing annual resolutions on oceans and fisheries and promoting informal discussions about oceans issues. However, the overall picture is of a plethora of institutions dealing with different aspects of oceans governance, with greater or lesser degrees of effectiveness. This fragmentation means that some environmental concerns can fall between the cracks and not be adequately addressed. ${ }^{52}$

The lack of an overarching decision-making body that can address issues related to the oceans more generally has been keenly felt. When new issues arise for which there is no obvious institutional home or even a set of legal rules, states have to attempt to deal with the problem within existing, specialised frameworks. This is evident in the response to questions around ocean iron fertilisation, which is now dealt with under the auspices of the Convention on the Prevention of Marine Pollution by Dumping of Wastes and Other Matter despite the fact that the activity is not actually "dumping" as defined by UNCLOS. ${ }^{53}$ Although states were ultimately able to reach agreement on how to respond to proposals for ocean fertilisation, arguably the response was significantly slowed by uncertainty and debate about the competence of the parties to the Convention to address the problem. ${ }^{54}$ These sorts of

49 Robin R Churchill and Geir Ulfstein "Autonomous Institutional Arrangements in Multilateral Environmental Agreements: A Little-Noticed Phenomenon in International Law" (2000) 94 AJIL 623; and Jutta Brunnée "COPing with Consent: Law-Making under Multilateral Environmental Agreements" (2002) 15 LJIL 1.

50 Julien Rochette and others "Regional oceans governance mechanisms: A review" (2015) 60 Mar Poly 9; and Julien Rochette and Raphaël Billé "Bridging the Gap between Legal and Institutional Developments within Regional Seas Frameworks" (2013) 28 IJMCL 433.

51 Rothwell and Stephens, above n 11, at 527.

52 Harrison, above n 2, at 276.

53 Convention on the Prevention of Marine Pollution by Dumping of Wastes and Other Matter, above n 15; and UNCLOS, art 1(5).

54 See for example Kerstin Güssow and others "Ocean iron fertilization: Why further research is needed" (2010) 34 Mar Poly 911 at 914; and Rosemary Rayfuse, Mark G Lawrence and Kristina M Gjerde "Ocean Fertilisation and Climate Change: The Need to Regulate Emerging High Seas Uses" (2008) 23 IJMCL 297 at 307. 
issues could be ameliorated if UNCLOS had created a decision-making framework more similar to MEAs, with competence over all oceans issues, that was capable of making new rules to respond to new challenges. ${ }^{55}$ However, this was rejected in the 1950s as "impracticable". 56

Another problem is that UNCLOS approached fisheries in particular with an old-fashioned approach to marine ecosystems. In the Convention, marine species are referred to as marine "living resources", a term that dates back to the 1958 Geneva Conventions, ${ }^{57}$ and earlier. This reflects a perspective that such species are economic units, similar to oil and minerals. Sustainability of these resources of necessity involves regulation of their exploitation, but they were not traditionally viewed as part of an ecosystem that needed to be managed as a whole. The idea of sustainable development, in which the interests of the environment need to be balanced against economic and social development, did not emerge until the 1980s. The importance of biodiversity emerged in the 1990s with the Convention on Biological Diversity. ${ }^{58}$ Some effort was put into expanding the scope of RFMO responsibilities in the UNFSA to include considerations of ecosystems and biodiversity. However, the extent to which RFMOs actually protect ecosystems from the impacts of fishing varies.

All of these structural problems have been long recognised. States have tried to counter them by improving sectoral institutions and negotiating new treaties to circumscribe state behaviour. However, there has never been sufficient political will to fundamentally reconsider the underlying structures of the law of the sea. This is why UNCLOS may never be truly successful as an environmental treaty. Although states can tinker with the rules around the edges, not all states are equally interested in achieving environmental protection, especially if it comes at an economic or social cost or involves the loss of perceived freedoms.

\section{$B$ Fisheries and Protection of Marine Biodiversity}

The structural limitations mentioned above have particularly impacted on the ability of UNCLOS and related instruments to ensure environmental protection in a fisheries/biodiversity context, particularly in areas beyond national jurisdiction. With the creation of EEZs, UNCLOS gave coastal states sufficient jurisdiction to sustainably manage the living resources and also to take steps to protect

55 See Rayfuse and Warner, above n 42, at 420.

56 Harrison, above n 2, at 298.

57 Convention on the High Seas 450 UNTS 11 (opened for signature 29 April 1958, entered into force 30 September 1962); Convention on the Continental Shelf 499 UNTS 311 (opened for signature 29 April 1958, entered into force 10 June 1964); Convention on the Territorial Sea and the Contiguous Zone 516 UNTS 205 (opened for signature 29 April 1958, entered into force 10 September 1964); and Convention on Fishing and Conservation of the Living Resources of the High Seas 559 UNTS 285 (opened for signature 29 April 1958, entered into force 20 March 1966).

58 Convention on Biological Diversity 1760 UNTS 79 (opened for signature 5 June 1992, entered into force 29 December 1993). 
marine biodiversity more generally. ${ }^{59}$ Beyond those areas under national jurisdiction, it is much more difficult to make progress due to the relatively weak provisions for protecting the high seas marine environment in UNCLOS. Any progress involving regulation of activities on the high seas relies on state agreement, through treaties and institutions, if they exist.

In light of the structural obstacles, it is noteworthy that significant progress has been made since the conclusion of UNCLOS in the regulation of fisheries beyond national jurisdiction. In particular, the 1995 UNFSA was an important step in expanding on the concept of cooperation in relation to straddling and highly migratory stocks. ${ }^{60}$ It reinforced that concepts such as protection of biodiversity, ecosystems management and the precautionary approach were to be implemented by RFMOs. ${ }^{61} \mathrm{It}$ established a framework for inspection of non-flag vessels on the high seas where the vessels are fishing in an area governed by an RFMO. ${ }^{62}$

Work done at a non-binding level has also been influential. The Food and Agriculture Organization's work in relation to illegal fishing and port state measures has been particularly important, with the latter leading to a treaty on the topic. ${ }^{63}$ The General Assembly, through its annual resolutions, has also had an impact on state behaviour. Two examples include the resolutions seeking the halt of large-scale driftnet fishing ${ }^{64}$ and the call for RFMOs to take steps to protect vulnerable marine ecosystems on the seabed from the impacts of destructive fishing practices. ${ }^{65}$

Despite this progress, it is possible to identify difficulties based on the structural issues discussed above. As already mentioned, many institutions do exist to manage fisheries in areas beyond national jurisdiction. While some of these RFMOs do appear to manage fishing effort sustainably, for many RFMOs they have not been entirely successful in achieving sustainability. One study has suggested that, although conservation is part of the mandate of all RFMOs, their priority appears to have been

59 In addition, the Convention on Biological Diversity imposes obligations on coastal states to achieve sustainable use of marine biodiversity in areas within their jurisdictions: arts 6-8.

60 Articles 7-8 in particular

61 Articles 5-6.

62 Articles 21-22.

63 Agreement on Port State Measures to Prevent, Deter and Eliminate Illegal, Unreported and Unregulated Fishing (2016) 55 ILM 1159 (opened for signature 22 November 2009, entered into force 5 June 2016).

64 Grant J Hewison "The Legally Binding Nature of the Moratorium on Large-Scale High Seas Driftnet Fishing" (1994) 25 J Mar L \& Com 557.

65 See for example Sustainable fisheries, including through the 1995 Agreement for the Implementation of the Provisions of the United Nations Convention on the Law of the Sea of 10 December 1982 relating to the Conservation and Management of Straddling Fish Stocks and Highly Migratory Fish Stocks, and related instruments GA Res 61/105 (2006). See BC O'Leary and others "The first network of marine protected areas (MPAs) in the high seas: The process, the challenges, and where next" (2012) 36 Mar Poly 598. 
to "guide the exploitation of fish stocks". ${ }^{66}$ The authors argue that the performance of many RFMOs is poor, pointing out that 67 per cent of the stocks assessed were depleted or overfished. ${ }^{67}$ While there have been many reasons suggested for the problems facing RFMOs, the following issues reflect the structural challenges mentioned above.

The freedom of the fishing on the high seas makes state agreement crucial. RFMOs do not cover the entire ocean or all fish stocks. The application of the freedom of the high seas in unregulated areas means that "the default position is that States can fish until they reach agreement not to fish". ${ }^{68}$ Gjerde and others point to the fact that, during negotiations for a South Pacific Fisheries Management Organisation and before the Convention came into force, a "race to fish" caused stocks of jack mackerel to drop from an estimated 30 million metric tonnes to less than 3 million metric tonnes. ${ }^{69}$ This is a reflection of the phenomenon known as the "tragedy of the commons". ${ }^{70}$

Where RFMOs do exist, they are not always effective. Frequently, the membership of the RFMO does not reflect all the states whose vessels are fishing for a stock. This means that a portion of the fishing effort remains unregulated by the RFMO. ${ }^{71}$ In addition, there is little coordination and cooperation among RFMOs, but also between RFMOs and other international institutions with responsibility for oceans. ${ }^{72}$

Another weakness is the fact that RFMOs often use consensus-based decision-making, which makes agreement on measures which involve curtailing fishing effort hard to achieve. ${ }^{73}$ Even where the RFMO has a majority-based decision-making process, states are usually able to object to a measure and opt out of implementing it. An interesting development in this space is the South Pacific

66 Sarika Cullis-Suzuki and Daniel Pauly "Failing the high seas: A global evaluation of regional fisheries management organizations" (2010) 34 Mar Poly 1036 at 1042.

67 At 1039.

68 Kristina M Gjerde and others "Ocean in peril: Reforming the management of global ocean living resources in areas beyond national jurisdiction" (2013) 74 Mar Pollut Bullet 540 at 544.

69 At 541 .

70 Andrew Serdy "Pacta Tertiis and Regional Fisheries Management Mechanisms: The IUU Fishing Concept as an Illegitimate Short-Cut to a Legitimate Goal" (2017) 48 Ocean Dev \& Intl L 345 at 346.

71 Brian Pentz and others "Can regional fisheries management organizations (RFMOs) manage resources effectively during climate change?" (2018) 92 Mar Poly 13 at 17.

72 Catherine Blanchard "Fragmentation in high seas fisheries: Preliminary reflections on a global oceans governance approach" (2017) 84 Mar Poly 327 at 328.

73 Gjerde and others, above n 68, at 543; and Antonia Leroy and Michel Morin "Innovation in the decisionmaking process of RFMOs" (2018) 97 Mar Poly 156 at 157-158. 
Regional Fisheries Management Organisation, which has a procedure which is designed to minimise the number of objections. ${ }^{74}$

Another issue is the phenomenon of illegal, unreported and unregulated fishing (IUU fishing). ${ }^{75}$ This descriptor describes certain types of behaviour that undermine sustainable fishing. The problems arise from areas where there is no regulatory body, where a fishing vessel is flagged to a state that has not acceded to an RFMO convention or is not a cooperating non-party, and where vessels flagged to a state party fail to follow the rules. While all of these problems have different origins and solutions, ${ }^{76}$ they generally reflect many of the structural issues mentioned above. These include a reluctance by some states to become bound by the conservation and management measures of RFMOs, as well as the difficulties of exercising jurisdiction over foreign vessels. A large suite of legal tools has been deployed to combat illegal fishing, including black and white lists of vessels, catch documentation schemes, electronic vessel monitoring, port state inspections and at-sea inspections making use of non-flag state boarding procedures established in the UNFSA. ${ }^{77}$ Although significant progress has been made at suppressing IUU fishing in some cases, the international community has not been able to eliminate it. ${ }^{78}$

Most RFMOs were established in an era when the importance of marine biodiversity was unknown. Although UNCLOS does contain some directives to states to consider the effects of fishing on associated or dependent species, ${ }^{79}$ awareness of ecosystems-based management concepts and modern management principles including the precautionary approach have developed since that time. Some RFMOs have updated their management instruments to allow themselves to take a broader

74 Howard S Schiffman "The South Pacific Regional Fisheries Management Organization (SPRFMO): an improved model of decision-making for fisheries conservation?" (2013) 3 J Environ Stud Sci 209 at 211.

75 The definition of these concepts can be found in the Food and Agriculture Organization's International Plan of Action to Prevent, Deter and Eliminate Illegal, Unreported and Unregulated Fishing (2 March 2001) at 23. See further Osvaldo Urrutia "Combating Unregulated Fishing through Unilateral Trade Measures: A Time for Change in International Fisheries Law?" (2018) 49 VUWLR 671.

76 Jens T Theilen "What's in a Name? The Illegality of Illegal, Unreported and Unregulated Fishing" (2013) 28 IJMCL 533 at 546.

77 See Food and Agriculture Organization The State of World Fisheries and Aquaculture 2018: Meeting the Sustainable Development Goals (2018) at 101.

78 In 2009 it was estimated that the total value of illegal and unreported fishing was between USD 10 and 23.5 billion per year in all parts of the ocean: David J Agnew and others "Estimating the Worldwide Extent of Illegal Fishing" (2009) 4(2) PLoS One e4570. The Food and Agriculture Organization is currently undertaking a process to achieve a more certain estimate of IUU fishing, although this has difficulties due to the inherent uncertainties behind the data: Food and Agriculture Organization Report of the Expert Workshop to Estimate the Magnitude of Illegal, Unreported and Unregulated Fishing Globally (Fisheries and Aquaculture Report No 1106 FIRO/R1106 (En), 4 February 2015).

79 Articles 61(4) and 119(1). 
range of measures to protect the marine environment. ${ }^{80}$ However, this development is piecemeal and some RFMOs have lagged behind in developing effective measures.

\section{INCREMENTAL CHANGE: LOOKING FORWARD}

The structural issues with UNCLOS have not prevented states and commentators from looking for improvements in the legal framework for the oceans. Incremental change can make significant inroads in filling the gaps in the governance system. This part of the article briefly examines two recent developments which have the potential to improve marine environmental management. First, a number of international courts and tribunals have begun to recognise the importance of environmental principles in regulating state behaviour. There is potential for these principles, which are found both in customary and treaty law, to be developed so that states have to give greater consideration to their environmental impact on the oceans. Second, the international community has begun to negotiate a new implementing agreement to UNCLOS focusing on the protection of marine biodiversity in areas beyond national jurisdiction. While it is still early days, this process could result in new institutional mechanisms and governance principles that will allow some of the weaknesses of UNCLOS to be addressed.

\section{A International Environmental Principles and the Law of the Sea in Dispute Settlement}

Incorporating new principles into existing legal frameworks is difficult. Treaties can take a long time, if ever, to amend. The amendment procedures in UNCLOS are particularly complicated, requiring ratification or accession by two thirds of the state parties. ${ }^{81}$ States are reluctant to renegotiate existing frameworks for fear of undermining the consensus that was achieved in the past. However, recent developments in the jurisprudence of international courts and tribunals has revived the role of customary international law in providing obligations on states in relation to the environment. In addition, states are increasingly focusing on the violation of environmental law treaty obligations in their disputes with one another. These developments have been relatively modest, but have underlined the possibility for dispute settlement processes to reinforce environmental obligations in the law of the sea.

One of the striking examples of this development was the Pulp Mills case, in which the International Court of Justice established important principles for managing transboundary harm. ${ }^{82}$ Among the obligations identified by the Court in that case was the obligation on a state to exercise due diligence in meeting its environmental duties, including the obligation to conduct an

80 Food and Agriculture Organization, above n 77, at 78.

81 Articles 312-316. See Yoshifumi Tanaka The International Law of the Sea (2nd ed, Cambridge University Press, Cambridge, 2015) at 32-33.

82 Pulp Mills on the River Uruguay (Argentina v Uruguay) (Merits) [2010] ICJ Rep 14. 
environmental impact assessment if there is a risk that an activity under the state's control may have a significant adverse impact in a transboundary context. ${ }^{83}$ The Court stated that the latter was a principle of customary international law. ${ }^{84}$ Although this was not a marine environmental protection case, it is a notable indication by the Court that it is willing to derive important environmental obligations for states from customary international law. ${ }^{85}$

These principles were referred to by the International Tribunal for the Law of the Sea (ITLOS) in its Advisory Opinion on activities in the Area. ${ }^{86}$ The Seabed Disputes Chamber of the Tribunal was asked to elaborate on the obligations of states that sponsored entities undertaking activities on the deep seabed (the Area). ITLOS noted that UNCLOS and relevant regulations issued by the International Seabed Authority contained important obligations. However, it also recognised that customary international law created obligations on states. In respect of the precautionary approach, the Tribunal suggested that the inclusion of the approach, as reflected in Principle 15 of the Rio Declaration, ${ }^{87}$ in treaties and other instruments "initiated a trend towards making this approach part of customary international law". 88 The Tribunal also suggested that a state that was required to exercise due diligence to meet environmental obligations in treaties may be required as a consequence to follow the precautionary approach. ${ }^{89}$ This was a significant step by an international tribunal to embed the precautionary approach into the corpus of the law of the sea in a way that goes further than the precise wording of particular treaties. ${ }^{90}$ It is possible that a future tribunal, interpreting the obligation in Article 192 of UNCLOS to protect and preserve the marine environment, might consider

83 At 82-83. See also Cymie R Payne "Pulp Mills on the River Uruguay: The International Court of Justice Recognizes Environmental Impact Assessment as a Duty under International Law" (2010) 14(9) ASIL Insight.

84 Pulp Mills on the River Uruguay, above n 82, at 83.

85 The Court's findings were reinforced and developed in Certain Activities Carried Out by Nicaragua in the Border Area (Costa Rica v Nicaragua) (Merits) [2015] ICJ Rep 665

86 Responsibilities and Obligations of States Sponsoring Persons and Entities with Respect to Activities in the Area (Advisory Opinion) (2011) 50 ILM 458. See David Freestone "Responsibilities and Obligations of States Sponsoring Persons and Entities with Respect to Activities in the Area" (2011) 105 AJIL 755; and Duncan French "From the Depths: Rich Pickings of Principles of Sustainable Development and General International Law on the Ocean Floor - the Seabed Disputes Chamber's 2011 Advisory Opinion" (2011) 26 IJMCL 525.

87 Report of the United Nations Conference on Environment and Development UN Doc A/CONF.151/26 (12 August 1992) vol 1.

88 Responsibilities and Obligations of States Sponsoring Persons and Entities with Respect to Activities in the Area, above n 86, at [135].

89 At [131].

90 French, above n 86, at 547; and Aline L Jaeckel The International Seabed Authority and the Precautionary Principle: Balancing Deep Seabed Mineral Mining and Marine Environmental Protection (Brill, Leiden, 2017) at 134-135. 
the application of the precautionary approach a part of the state's obligation to exercise due diligence to implement Article 192.

The Tribunal was also keen to point out that the obligations on states to conduct environmental impact assessments sprang from customary international law as well as treaty law. ${ }^{91}$ It referred to the Pulp Mills decision, and stated that the ICJ's: ${ }^{92}$

... reasoning in a transboundary context may also apply to activities with an impact on the environment

in an area beyond the limits of national jurisdiction; and the Court's references to 'shared resources' may

also apply to resources that are the common heritage of mankind ...

Another way in which tribunals have contributed to the incorporation of environmental principles is in the interpretation of UNCLOS, particularly Article 192. A second advisory opinion was issued by ITLOS at the request of the Sub-Regional Fisheries Commission in $2015 .{ }^{93}$ Although the focus was on the responsibility of states for IUU fishing, the Tribunal briefly addressed the relationship between Article 192 and the responsibility of flag states to ensure their vessels comply with coastal state measures. The Tribunal noted that the conservation and management of living resources is linked with the protection and preservation of the marine environment. ${ }^{94}$

The most significant recent decision on marine environmental protection is the arbitral award in the South China Sea Arbitration. ${ }^{95}$ The Tribunal found that China had failed to prevent its fishermen from harvesting endangered marine species ${ }^{96}$ and that its construction of artificial islands has had a significant adverse impact on the marine environment. ${ }^{97}$ The Tribunal read the obligation in Article 192 in light of the instruction in Article 194(5) to take measures necessary to protect and preserve rare or fragile ecosystems. It also considered that Article 192 must be "read against the background of

91 Responsibilities and Obligations of States Sponsoring Persons and Entities with Respect to Activities in the Area, above n 86, at [145].

92 At [148].

93 Request for an Advisory Opinion Submitted by the Sub-Regional Fisheries Commission (Advisory Opinion) (2015) 54 ILM 893.

94 At [120], citing Southern Bluefin Tuna (New Zealand v Japan) (Provisional Measures) [1999] ITLOS Rep 280 at $[70]$.

95 South China Sea Arbitration (Philippines v China) (Award) PCA 2013-19, 12 July 2016. See also Tim Stephens "The Collateral Damage From China's 'Great Wall of Sand' - The Environmental Dimensions of the South China Sea Case" (2017) 34 Aust YBIL 41; and Stephen Fietta, Jiries Saadeh and Laura Rees-Evans "The South China Sea Award: A Milestone for International Environmental Law, the Duty of Due Diligence and the Litigation of Maritime Environmental Disputes?" (2017) 29 Geo Intl Envtl L Rev 711.

96 South China Sea Arbitration, above n 95, at [950].

97 At [979]. 
other applicable international law". ${ }^{98}$ The Tribunal referred to China's acceptance of the Convention on International Trade in Endangered Species of Wild Fauna and Flora (CITES) ${ }^{99}$ and stated that Article 192 imposes a due diligence obligation that "extends to the prevention of harms that would affect depleted, threatened, or endangered species indirectly through the destruction of their habitat". ${ }^{100}$ In relation to the construction of artificial islands, the Tribunal concluded that China had breached its obligations under arts 192 and $194 .{ }^{101}$ It observed that China owed obligations to cooperate that stemmed from UNCLOS. ${ }^{102}$ The Tribunal also found that China bore obligations to conduct an environmental impact assessment, based on Article 206 of UNCLOS. ${ }^{103}$

What is notable about the South China Sea Arbitration is the clear connection between the failure to take steps to protect vulnerable marine species from exploitation and the obligation to protect the environment. Also interesting is that China's membership of CITES appears to have been taken into account in applying Article 192, and also that the Convention on Biological Diversity was used to interpret the meaning of "ecosystem" in Article 194. ${ }^{104}$

It is possible that states may increasingly turn to international dispute settlement to resolve matters around marine environmental protection. It is unlikely to be a cure-all, however. To be effective, we would need to see clear evidence that the pronouncements of tribunals as to the law are being implemented widely in state practice. In addition, the ability of decisions of courts and tribunals to adjust state behaviour is potentially limited. Recently Russia and China have rejected the jurisdiction of tribunals formed under Part XV of UNCLOS, which may limit the influence of adjudicatory bodies. ${ }^{105}$ There is also the fact that customary international law is not best suited for the development of a precise body of environmental rules. States have tended to prefer establishing rules through treaty regimes. ${ }^{106}$ Therefore, the impact of such cases may be limited to bilateral or local disputes.

98 At [959].

99 Convention on International Trade in Endangered Species of Wild Fauna and Flora 993 UNTS 243 (opened for signature 3 March 1973, entered into force 1 July 1975).

100 South China Sea Arbitration, above n 95, at [959].

101 At [983]

102 At [984]-[985].

103 At [988].

104 At [945]

105 See Philippines v China (Jurisdiction and Admissibility) PCA 2013-19, 29 October 2015; and Arctic Sunrise Arbitration (Netherlands v Russia) (Award) (2015) 55 ILM 5.

106 Oxman, above n 30, at 117. 


\section{B Protection of Marine Biodiversity in Areas Beyond National Jurisdiction}

A second, and possibly more significant development, is represented by the current negotiations in the United Nations for a new international legally binding instrument for the protection of marine biodiversity in areas beyond national jurisdiction. In 2017 the General Assembly agreed to begin negotiations for a new internationally binding instrument. ${ }^{107}$ The treaty must be consistent with UNCLOS, but one of the key goals is to address gaps in the existing legal framework. The areas that have been focused on by the discussions so far have been the legal regime for marine genetic resources, area-based management, environmental impact assessment and capacity building. It has been suggested that the new agreement could require states to comply with important environmental principles including the precautionary approach, ecosystem-based management, cooperation and stewardship. ${ }^{108}$

In addition, some have argued that the agreement could create institutional frameworks and establish a legal regime for the exploitation of marine genetic resources. ${ }^{109}$ Many suggestions for the agreement have focused on creating an institution. Some have argued for a body with legislative functions, while others prefer to see something limited to coordination or recommendatory functions. ${ }^{110}$ The issue of marine genetic resources is possibly the most contentious substantive legal topic that will need to be addressed by the agreement. It also poses the greatest risk of derailing consensus on a new treaty.

There are a number of obstacles to the conclusion of the new agreement. One problem is the extent to which the agreement will interact with existing global and regional bodies, such as RFMOs. The

107 International legally binding instrument under the United Nations Convention on the Law of the Sea on the conservation and sustainable use of marine biological diversity of areas beyond national jurisdiction GA Res 72/249 (2017).

108 Penelope Ridings "Redefining environmental stewardship to deliver governance frameworks for marine biodiversity beyond national jurisdiction" (2018) 75 ICES J Mar Sci 435; Katherine Houghton "Identifying new pathways for ocean governance: The role of legal principles in areas beyond national jurisdiction" (2014) 49 Mar Poly 118; and Alex G Oude Elferink "Governance Principles for Areas Beyond National Jurisdiction" (2012) 27 IJMCL 205.

109 Tullio Scovazzi "The negotiations for a binding instrument on the conservation and sustainable use of marine biological diversity beyond national jurisdiction" (2016) 70 Mar Poly 188; and Elisabeth Druel and Kristina M Gjerde "Sustaining marine life beyond boundaries: Options for an implementing agreement for marine biodiversity beyond national jurisdiction under the United Nations Convention on the Law of the Sea" (2014) 49 Mar Poly 90.

110 Margaret A Young and Andrew Friedman "Biodiversity Beyond National Jurisdiction: Regimes and their Interaction" (2018) 112 AJIL Unbound 123. 
General Assembly has stipulated that the agreement must not undermine existing organisations. ${ }^{111}$ If the agreement does introduce mechanisms for modern environmental governance, but fails to extend these to existing institutions such as RFMOs, then the possible impact of the agreement could be drastically limited. Given the key sectoral activities in areas beyond national jurisdiction are currently subject to a fragmented legal framework, the agreement could fail to achieve much progress in moving towards a more integrated legal framework. Some states, for whom the current (inadequate) system of managing fisheries resources is consistent with their perceived national interest, will seek to ensure the new agreement is weak or is not finalised. This would be disappointing, but the roots of that disappointment lie in the structural limitations of UNCLOS already discussed.

\section{CONCLUSION}

A recent study has shown that only around 13 per cent of the oceans can be said to be true wilderness areas, with biologically and ecologically intact seascapes that are mostly free of human disturbances. ${ }^{112}$ Most of these are located on the high seas and most in the Pacific or in the Southern Ocean. The impact of climate change on these areas is likely to be extreme. ${ }^{113}$ Human activity has affected the vast majority of our oceans. Given this troubling statistic, the ability of UNCLOS and the law of the sea more generally to protect the marine environment will become more critical than ever in the near future.

UNCLOS was a grand package deal that pushed the limits of existing regulation in many ways, but at its heart it left intact structural problems that remain today. States have done their best to push the legal framework towards a more sustainable future, but the dynamic evolution of the law of the sea has, thus far, failed to address the key problems at the core of UNCLOS. This is not a criticism of those who drafted UNCLOS. The diplomats negotiating UNCLOS, while more aware of the marine environment than previously, never could have imagined the scale of human impacts on the oceans that is seen today. In addition, vested interests in the economic exploration of the oceans likely prevented a more radical shake-up of the existing order.

Is there hope that the law of the sea will evolve into a more robust system for environmental protection? Climate change is predicted to exacerbate the existing problems in managing the marine environment, so the issue is becoming more urgent than ever before. We are seeing some signs of hope in the increasing reference to environmental principles in dispute settlement and the prospects of a new agreement on sustainable use of marine biodiversity beyond national jurisdiction. There have always been states pushing the international system to perform better through incremental

111 International legally binding instrument under the United Nations Convention on the Law of the Sea, above n 107, at [7].

112 Kendall R Jones and others "The Location and Protection Status of Earth's Diminishing Marine Wilderness" (2018) 28 Curr Biol 2506.

113 At 2510 . 
improvements to the legal framework. The serious question is whether this will be sufficient, and timely enough, to prevent further deterioration of the marine environment. Despite Philip Allott's hope that UNCLOS would usher in a new age of international law aimed at protecting social objectives, the traditional view of international law as existing for the protection of state interests appears to have not released its grip on the law of the sea. His suggestion was that we consider that "[t]he sea is our sea because we find ourselves to be cohabitants with the sea on the planet Earth and because all human beings naturally share its potentialities." 114 Perhaps it is not too late.

114 Allott, above n 3, at 773 
